\title{
The impact of recovery by cold water immersion on some immunoglobulin for young swimmers
}

\section{By: Assistant prof : Mohammad Hamed Mohammad Fahmy}

\section{Introduction \& Research's problem:}

The main target of sporting training for athletes specially with high levels is to increase the levels of performance through the contests; so the success is a must to achieve the harmony between the training loads and the different recovery operations to attain super- compensation . on the contarary, the failure to achieve this harmony leads to overtraining which connects with many passive changes in the biochemical; immune; psychological and physiological and may cause injury variables and decrease the performance.(33)

The training load represents pressure on the different body parts producing many varied responses according to the type; the period and the hardness of training sued. The immune system is affected by these training loads aiming to protect the body from diseases, The attain to overtraining leads to decrease the functions of the immune system; and to decrease the ability of the body to with stand the infections and to cause diseases for athletes.(2)(4)(28)(55)

the immune system in the body of athletes relies on what the T-cells make as a helper for B-cells, to urge for producing antibodies like immunoglobulin (Ig), There are multi - immunoglobulin in the blood like ( $\operatorname{IgA}, \operatorname{IgM}, \operatorname{IgG}, \operatorname{IgE}, \operatorname{IgD})$ have the ability to respond against the antigens .$(6: 220)(17)(43)(19)(65)$

The process of recovery is considered various and multi - sides connecting with other processes inside the different training units as the degree of tiredness; training dose; body load and distributing the physical loads for the different periods of training season starting from the daily training dose and weekly load cycle. Cold water immersion (CWI) is recently considered a means of recovery for athletes used by specialist of physical preparation programs in different sports because it depends on a group at physiological mechanisms as vasoconstriction of blood vessels and muscle tissue cooling which lead to the decrease of blood flow, fatigue perception and delayed - onset muscle soreness (DOMS) and oxidative stress .(1:53,54)(3:292)(22)(23)(36)(46)(56)(58)(64)

Through the researcher's task as a technical coach in the national teams of basketball obtaining $2^{\text {nd }}$ position in Africa (2015) and $3^{\text {rd }}$ position in Africa (2017), he noticed that there are many passive changes occurred for the athletes when the African and international competitions approach like tiredness, cold cases and sudden diseases for female players without any clear reasons. One of these reasons may lead to weakness and shortage in the immune functions for the athletes in this period because of existing high training loads and increasing the physical and psychological pressures, so the means of recovery used much 
more anytime before to prepare the athletes for training units continuously with high tensions unscientifically by fast responses in the immune changes for the athletes whether after the high training units or after the different means of recovery used. Therefore the researcher tried to identify the effectiveness of different recovery means (cold water immersion - massage - passive recovery)on some immune changes for serum immunoglobulin levels ( IgG, $\operatorname{IgM}, \operatorname{IgA})$ in the blood during the period before the contests and after the high - pressure weekly cycle for young swimmers .

\section{Research's Aims :}

1. Identifying the level of concentration ( IGG, IGM, IGA ) in the blood for the swimmers before and after dimensions (after finishing weekly load cycle directly in the recovery dimensions ( cold water immersion, massage and passive recovery for young swimmers.

2. Comparing and finding the differences in the level of concentration ( IGG, IGM, IGA ) in the blood among (before dimension - after dimension - recovery dimension ) for the group of cold water immersion

3. Comparing and finding differences in the level of concentration ( IGG, IGM, IGA ) in the blood among (before dimension - after dimension recovery dimension ) for the group of massage .

4. Comparing and finding differences in the level of concentration ( IGG, IGM, IGA ) in the blood among (before dimension - after dimensionrecovery dimension ) for the group of passive recovery .

5. Comparing and finding differences in the level of concentration (IGG, IGM, IGA ) in the blood among the groups (immersion in ice - massage - passive recovery) in the recovery dimension .

\section{Research's Question :}

1. What are the changes occurred in the ratio of concentration (IGG, IGM, IGA ) in the blood in the after dimension as a result of training loads performance for high - tension weekly cycle for young swimmer's ?

2. What are the changes occurred in the ratio of concentration (IGG, IGM, IGA ) in the blood among the recovery dimension as a result of using the means of recovery ( cold water immersion - massage - passive recovery ) for young swimmers ?

\section{Research's procedures}

Research's approach \& sample

The researcher used the experimental approach by designing the before and after dimensions by one group, the sample contained (12) swimmers between (16-18) years chosen haphazardly from the ones listed in Zamalek, Ahly, Qahira, Tersana, Wadi Degla, and Tanta clubs .

\section{Research's experimental design :}

The research designed the research's sample by dividing into (3) groups : (4) swimmers for each, two experimental groups and the third for controlling 
group. The $1^{\text {st }}$ one for cold water immersion, the $2^{\text {nd }}$ for massage and the last one for passive recovery depending on the before and after style - recovery .

\section{Research's sample's description :}

1. The personal motivation is a must for swimmers to share in the study; complete knowledge must be available.

2. Approval of sample's individuals to draw blood samples in the different dimensions is a must . (Appendix 1)

\section{Table ( 1 )}

Statistic description of research's sample in the variables of age, Height, weight, and training era $\mathrm{N}=12$

\begin{tabular}{c|c|c|c|c|c}
\hline Serial & $\begin{array}{c}\text { Unit of } \\
\text { measurement }\end{array}$ & SMA & $\begin{array}{c}\text { Standard } \\
\text { deviation }\end{array}$ & Median & $\begin{array}{c}\text { Coefficient } \\
\text { of torsion }\end{array}$ \\
\hline Age & Yrs. & 17.75 & 1.815 & 16.36 & 1.320 \\
\hline Height & c.m. & 173.08 & 4.501 & 172.33 & 0.439 \\
\hline Weight & k.g. & 71.00 & 3.275 & 70.26 & 0.373 \\
\hline Training era & Yrs & 10.08 & 1.311 & 10.00 & 0.110 \\
\hline
\end{tabular}

It's shown from table (1) that the values of coefficient of torsion for age, Height, weight and training era were between ( $3 \pm$ ), so the sample is homogeneous.

\section{Table ( 2 )}

Analysis of variance among the outcomes of before dimensions for research's groups ( cold water immersion - massage - passive recovery ) of study's variables

\begin{tabular}{|c|c|c|c|c|c|c|}
\hline Measurements & Source of variance & $\begin{array}{l}\text { Total of } \\
\text { squares }\end{array}$ & $\begin{array}{c}\text { Degree } \\
\text { of } \\
\text { liberty }\end{array}$ & $\begin{array}{c}\text { Average } \\
\text { of total } \\
\text { squares }\end{array}$ & $\begin{array}{c}\text { F. } \\
\text { value }\end{array}$ & Indication \\
\hline $\operatorname{Ig} \mathrm{A}$ & $\begin{array}{l}\text { Among groups } \\
\text { Inside groups } \\
\text { Total }\end{array}$ & $\begin{array}{c}3.500 \\
2582.500 \\
2586.00\end{array}$ & $\begin{array}{c}2 \\
9 \\
11\end{array}$ & $\begin{array}{c}1.750 \\
286.944\end{array}$ & 0.006 & 0.994 \\
\hline $\operatorname{IgM}$ & $\begin{array}{l}\text { Among groups } \\
\text { Inside groups } \\
\text { Total }\end{array}$ & $\begin{array}{c}18.000 \\
621.000 \\
639.000\end{array}$ & $\begin{array}{c}2 \\
9 \\
11\end{array}$ & $\begin{array}{c}9.000 \\
69.000\end{array}$ & 0.130 & 0.879 \\
\hline IgG & $\begin{array}{l}\text { Among groups } \\
\text { Inside groups } \\
\text { Total }\end{array}$ & $\begin{array}{c}15.500 \\
3872.500 \\
3888.000\end{array}$ & $\begin{array}{c}2 \\
9 \\
11\end{array}$ & $\begin{array}{c}7.750 \\
430.278\end{array}$ & 0.018 & 0.982 \\
\hline
\end{tabular}

F value at $(.05)=3.68$

It's shown from table ( 2 ) that there aren't any statistically differences among the outcomes of before dimensions in (IgA, $\operatorname{IgM}, \operatorname{IgG})$ for the groups of research, so the sample is homogeneous .

\section{Tools \& sets used :}

1. A form is designed to list the data for each person for blood samples of the three dimensions before, after and recovery . (Appendix 2) .

2. A swimming pool is used to implement the training doses proposed for young swimmers .

3. A stopwatch to count the times of repetitions, recoveries between repetitions and groups to implement the training doses proposed . 
4. A centrifuge set to separate the blood compositions and a spectrophotometer .

5. An iced fiberglass basin connected with a thermometer to identify the temperature inside .

6. Medical oil for massage and treatment couch .

7. Sterile dried plastic pipes with a cover to keep the blood samples to transfer to labs .

8. A group of plastic syringes 5 c.m. cotton and plaster .

9. Kits to identify the biochemical variables .

\section{Steps of research's experiment :}

- The biochemical before dimensions were taken by the blood samples for all swimmers (all the persons of the sample) in Ahly bank club in Cairo dated 17/8/2019 before the starting of mini-training load cycle .

- Weekly training units were implemented dated 17/8/2019 till 22/8/2019 : each mini-training load unit contained (6) intensive stress weekly training units during the period of competitions : one unit each day .

\section{Steps \& instructions and procedures of final training dose and executing} recovery unit

- All the persons of sample; the researcher; massage specialist; analysis specialist and the training team of swimmer attended to cooperate with the researcher to finalize the last training unit dated 22/8/2019 6.a.m. exactly in Ahly bank club, Cairo, though the warming up will be done through just little jogging and stretching and flexibility exercises trainings for (25) mins . to lift the body's temperature and make the body ready for physical performance .

- The after dimension is done after the last training unit done; it divided into three groups with a different recovery means. The $1^{\text {st }}$ one is cold water immersion, the $2^{\text {nd }}$ one is massage and last is for passive recovery; finally the recovery dimension is done (IGA), (IGM), (IGG).

\section{Steps of recovery unit :}

It's divided into (3) equal groups, (4) swimmers for each. (2) experimental groups and the one is controlling. The $1^{\text {st }}$ one is cold water immersion for (10) mins. Temp. is $\left(14 \mathrm{c}^{\mathbf{o}}\right)$ by iced fiberglass basin connected with a thermometer fixed inside. The $2^{\text {nd }}$ one is for a massage (20) mins. And last for passive recovery (20) mins .

\section{Table ( 3 )}

Sequence \& timing done for massage of different parts of the body for search's sample

\begin{tabular}{c|c|c|c|c|c|c|c}
\hline Body's muscles & $\begin{array}{c}\text { Front\& } \\
\text { connective } \\
\text { muscles }\end{array}$ & $\begin{array}{c}\text { Back } \\
\text { thigh } \\
\text { muscles }\end{array}$ & $\begin{array}{c}\text { Leg } \\
\text { muscles }\end{array}$ & $\begin{array}{c}\text { Back } \\
\text { muscles }\end{array}$ & $\begin{array}{c}\text { Upper } \\
\text { arm\& } \\
\text { shoulder } \\
\text { muscles }\end{array}$ & Sole & Total \\
\hline Massage & 4 mins & 4 mins & 3 mins & 4 mins & 3 mins & 2 mins & 20mins \\
\hline
\end{tabular}


- The persons of sample were gathered once more after recovery to draw blood samples in the recovery dimension. It's (10) a.m. exactly the experiment was completed.

- The samples of blood were transferred to medical labs in Cairo to analyze the biochemical variables .

Display \& debate and explanation of the outcomes firstly :

First : research's outcomes :

Table ( 4 )

Analysis of variance among research's measurements (before - after recovery ) for cold water immersion group in the study variables $N=4$

\begin{tabular}{|c|c|c|c|c|c|c|}
\hline Measurements & $\begin{array}{l}\text { Source of } \\
\text { variance }\end{array}$ & $\begin{array}{l}\text { Total of } \\
\text { squares }\end{array}$ & $\begin{array}{l}\text { Degree } \\
\text { of } \\
\text { liberty }\end{array}$ & $\begin{array}{l}\text { Average of } \\
\text { total } \\
\text { squares }\end{array}$ & $\begin{array}{c}\text { F. } \\
\text { value }\end{array}$ & Indication \\
\hline $\operatorname{IgA}$ & $\begin{array}{l}\text { Among groups } \\
\text { Inside groups } \\
\text { Total }\end{array}$ & $\begin{array}{c}24317.167 \\
6171.500 \\
30488.667\end{array}$ & $\begin{array}{c}2 \\
9 \\
11\end{array}$ & $\begin{array}{c}12158.583 \\
685.722\end{array}$ & 17.731 & .001 \\
\hline IgM & $\begin{array}{l}\text { Among groups } \\
\text { Inside groups } \\
\text { Total }\end{array}$ & $\begin{array}{c}13834.667 \\
4194.000 \\
18028.667\end{array}$ & $\begin{array}{c}2 \\
9 \\
11\end{array}$ & $\begin{array}{c}6917.333 \\
466.000\end{array}$ & 14.844 & .001 \\
\hline $\mathrm{IgG}$ & $\begin{array}{l}\text { Among groups } \\
\text { Inside groups } \\
\text { Total }\end{array}$ & $\begin{array}{l}146930.167 \\
130384.750 \\
277314.917\end{array}$ & $\begin{array}{c}2 \\
9 \\
11\end{array}$ & $\begin{array}{l}73465.083 \\
14487.194\end{array}$ & 5.071 & .034 \\
\hline
\end{tabular}

( $\mathrm{F}$ ) value at $(.05)=3.68$

It's shown from table ( 4 ) that (ANOVA) for research's measurements ( before - after - recovery ) for cold water immersion group in the variables of study (IgA), (IgM), (IgG). There are moral differences among the three dimensions (before - after - recovery ), $(F)$ value between $(5.07,17.73)$ and this value is greater than in the table at (.05) to limit the differences the (LSD) is used in table (5) .

\section{Table ( 5 )}

The indication of differences among research's measurement outcomes (before - after - recovery ), for cold water immersion group in the study's variables by using the least moral difference ( LSD ) .

\begin{tabular}{c|c|c|c|c|c|}
\hline Measurements & Groups & Averages & Before & After & recovery \\
\hline \multirow{3}{*}{ IgA } & Before & 259.7 & & 53.50 & 56.75 \\
\cline { 2 - 6 } & After & 313.00 & 53.50 & & 110.25 \\
\cline { 2 - 6 } & Recovery & 203.00 & 56.75 & 110.25 & \\
\hline \multirow{3}{*}{ IgM } & Before & 141.00 & & 65.00 & 14.00 \\
\cline { 2 - 6 } & After & 205.00 & 46.00 & & 78.00 \\
\cline { 2 - 6 } & Recovery & 127.00 & 14.00 & 78.00 & \\
\hline \multirow{3}{*}{ IgG } & Before & 1126.3 & & 139.75 & 131.25 \\
\cline { 2 - 6 } & After & 1266.00 & 139.75 & & 271.00 \\
\cline { 2 - 6 } & Recovery & 995.00 & 131.25 & 271.00 & \\
\hline
\end{tabular}

It's shown from table ( 5 ) that there are statistically differences among the outcomes of the three research dimensions (before - after - recovery ), for cold water immersion group in the study's variables (IgA), (IgM), (IgG). The indication of differences between before and after differences for the sake of 
after dimension, and between after and recovery for the sake of after dimension

\section{Table ( 6 )}

Ration of changes between before and after dimension outcomes for cold water immersion group $N=4$

\begin{tabular}{c|c|c|c|c|c|c}
\hline \multirow{2}{*}{ Variables } & \multirow{2}{*}{ Measurement unit } & \multicolumn{2}{|c|}{ Before dimension } & \multicolumn{2}{c|}{ after dimension } & \multirow{2}{*}{ Ratio \% } \\
\cline { 3 - 6 } & & $\mathbf{M}$ & $\mathbf{A}$ & $\mathbf{M}$ & $\mathbf{A}$ & \multirow{2}{*}{} \\
\hline $\mathrm{IgA}$ & $\mathrm{Mg} / \mathrm{dl}$ & 259.7 & 7.96 & 313.00 & 13.25 & $20.52 \%$ \\
\hline $\mathrm{IgM}$ & $\mathrm{Mg} / \mathrm{dl}$ & 141 & 14.33 & 205.00 & 15.55 & $45.39 \%$ \\
\hline $\mathrm{IgA}$ & $\mathrm{Mg} / \mathrm{dl}$ & 1126.3 & 165.5 & 1266.0 & 206.8 & $12.40 \%$ \\
\hline
\end{tabular}

It's shown from table ( 6 ) that the change ratios in the study variables $(\operatorname{IgA})$, $(\operatorname{IgM}),(\operatorname{IgG})$ between before and after differences for cold water immersion were $12.40 \%-45.39 \%$.

Table ( 7 )

Ratios of changes between the outcomes of the after and recovery dimensions for cold water immersion group in the study variables $N=4$

\begin{tabular}{c|c|c|c|c|c|c}
\hline \multirow{2}{*}{ Variables } & \multirow{2}{*}{ Measurement unit } & \multicolumn{2}{|c|}{ After dimension } & \multicolumn{2}{c|}{ Recovery . dimension } & \multirow{2}{*}{ Ratio \% } \\
\cline { 3 - 6 } & & $\mathbf{M}$ & $\mathbf{A}$ & $\mathbf{M}$ & $\mathbf{A}$ & \\
\hline $\mathrm{IgA}$ & $\mathrm{Mg} / \mathrm{dl}$ & 313.00 & 13.25 & 203 & 41.36 & $35.14 \%$ \\
\hline $\mathrm{IgM}$ & $\mathrm{Mg} / \mathrm{dl}$ & 205.00 & 15.55 & 127 & 33.14 & $38.04 \%$ \\
\hline $\mathrm{IgA}$ & $\mathrm{Mg} / \mathrm{dl}$ & 1266.0 & 206.8 & 995.00 & 12.17 & $21.40 \%$ \\
\hline
\end{tabular}

It's shown from table ( 7 ) that the ratios of changes in the study variables (IgA), (IgM), (IgG) between the after and recovery differences for cold water immersion group were $(21.40 \%-38.04 \%)$.

\section{Table ( 8 )}

Variance analysis among research's measurements outcomes (before after-recovery ) for massage group in the study variables $N=4$

\begin{tabular}{|c|c|c|c|c|c|c|}
\hline Measurements & $\begin{array}{c}\text { Source of } \\
\text { variance }\end{array}$ & $\begin{array}{l}\text { Total of } \\
\text { squares }\end{array}$ & $\begin{array}{c}\text { Degree } \\
\text { of } \\
\text { liberty }\end{array}$ & $\begin{array}{c}\text { Average of } \\
\text { total } \\
\text { squares }\end{array}$ & $\begin{array}{c}\text { F. } \\
\text { value }\end{array}$ & Indication \\
\hline \multirow{3}{*}{$\operatorname{IgA}$} & Among groups & 6435.500 & 2 & 3217.750 & 3.915 & $.060 \%$ \\
\hline & Inside groups & 7396.750 & 9 & 821.861 & & \\
\hline & Total & 13832.250 & 11 & & & \\
\hline \multirow{3}{*}{$\operatorname{IgM}$} & Among groups & 7971.167 & 2 & 3985.583 & 7.901 & $.010 \%$ \\
\hline & Inside groups & 4539.750 & 9 & 504.417 & & \\
\hline & Total & 12510.917 & 11 & & & \\
\hline \multirow{3}{*}{$\operatorname{IgG}$} & Among groups & 41873.167 & 2 & 20936.583 & 1.244 & $.344 \%$ \\
\hline & Inside groups & 151517.750 & 9 & 16835.306 & & \\
\hline & Total & 193390.917 & 11 & & & \\
\hline
\end{tabular}

( $\mathrm{F})$ value at $(0.05)=3.68$

It's shown from table ( 8 ) that variance analysis (ANOVA) among the research dimensions ( before - after - recovery ) for massage group in (IgA), $(\operatorname{IgM})$, (IgG). There are moral differences among the three dimensions (before - after recovery ), $(\mathrm{F})$ value (1.244-7.901). and this value is greater than $(\mathrm{F})$ value in the table at $(0.05)$ to limit the differences indications among the three dimensions in these variables; the least moral difference is used LSD in table (9) . 
Table ( 9 )

Differences indication among research's dimensions outcomes (before - after recovery ), for massage group in the study variables by least moral difference (

LSD).

\begin{tabular}{c|c|c|c|c|c}
\hline Measurements & Groups & Averages & Before & After & Recovery \\
\hline \multirow{3}{*}{ IgA } & Before & 259.50 & & 52.25 & 7.00 \\
\cline { 2 - 6 } & After & 311.75 & 52.25 & & 45.25 \\
\cline { 2 - 6 } & recovery & 266.50 & 7.00 & 45.25 & \\
\hline \multirow{3}{*}{ IgM } & Before & 144.00 & & 61.75 & 19.50 \\
\cline { 2 - 6 } & After & 205.75 & 61.75 & & 42.25 \\
\cline { 2 - 6 } & recovery & 163.50 & 19.50 & 42.25 & \\
\hline
\end{tabular}

It's shown from table ( 9 ) that there are statistically differences among the three dimensions outcomes (before - after - recovery ), for massage group in variables of $(\operatorname{IgA}),(\operatorname{IgM})$ There are differences between before and after differences for the sake of after dimension, and between after and recovery dimension for the sake of after dimension too .

Table ( 10 )

Ration of changes between the outcomes of before and after dimensions for massage group in the study variables $N=4$

\begin{tabular}{|c|l|l|l|l|l|l|}
\hline \multirow{2}{*}{ Variables } & \multirow{2}{*}{ Measurement unit } & \multicolumn{2}{|c|}{ Before dimension } & \multicolumn{2}{|c|}{ After dimension } & \multirow{2}{*}{ Ratio \% } \\
\cline { 3 - 6 } & & \multicolumn{1}{|c|}{$\mathbf{M}$} & \multicolumn{1}{|c|}{$\mathbf{A}$} & $\mathbf{A}$ & \\
\hline $\mathrm{IgA}$ & $\mathrm{Mg} / \mathrm{dl}$ & 259.5 & 8.54 & 311.75 & 14.174 & $20.13 \%$ \\
\hline $\mathrm{IgM}$ & $\mathrm{Mg} / \mathrm{dl}$ & 144.5 & 15.23 & 205.75 & 17.500 & $42.39 \%$ \\
\hline $\mathrm{IgA}$ & $\mathrm{Mg} / \mathrm{dl}$ & 123.5 & 170.8 & 1239.75 & 211.849 & $10.35 \%$ \\
\hline
\end{tabular}

It's shown from table ( 10 ) that the change ratios in the study variables (IgA), (IgM), (IgG) between before and after differences for massage group were $(10.35 \%-42.39 \%)$.

Table ( 11 )

Change ratios between the outcomes of after and recovery dimension for massage group in the study variables $N=4$

\begin{tabular}{c|c|c|c|c|c|c}
\hline \multirow{2}{*}{ Variables } & \multirow{2}{*}{ Measurement unit } & \multicolumn{2}{|c|}{ After dimension } & \multicolumn{2}{c|}{ Recovery . dimension } & \multirow{2}{*}{ Ratio \% } \\
\cline { 3 - 6 } & & $\mathbf{M}$ & $\mathbf{A}$ & $\mathbf{M}$ & $\mathbf{A}$ & \\
\hline $\mathrm{IgA}$ & $\mathrm{Mg} / \mathrm{dl}$ & 311.75 & 14.174 & 266.50 & 44.575 & $14.51 \%$ \\
\hline $\mathrm{IgM}$ & $\mathrm{Mg} / \mathrm{dl}$ & 205.75 & 17.500 & 163.50 & 33.867 & $20.35 \%$ \\
\hline $\mathrm{IgA}$ & $\mathrm{Mg} / \mathrm{dl}$ & 1239.75 & 211.849 & 1104.00 & 72.974 & $10.73 \%$ \\
\hline
\end{tabular}

It's shown from table ( 11 ) that the change ratios in the study variables (IgA), (IgM), (IgG) between the after and recovery differences for massage group were $(10.37 \%-20.35 \%)$.

Table ( 12 )

Variance analysis among research's dimensions outcomes (before - after recovery ) for passive recovery $N=4$

\begin{tabular}{c|c|c|c|c|c|c}
\hline Measurements & Source of variance & Total squares & $\begin{array}{c}\text { Degree of } \\
\text { liberty }\end{array}$ & $\begin{array}{c}\text { Average of } \\
\text { squares total }\end{array}$ & F. value & Indication \\
\hline \multirow{2}{*}{ IgA } & Among groups & 5862.500 & 2 & 2931.250 & 1.137 & .174 \\
& Inside groups & 12343.750 & 9 & 1371.528 & & \\
\hline \multirow{2}{*}{ IgM } & Total & 18206.250 & 11 & & & .002 \\
& Among groups & 8936.167 & 2 & 4468.083 & 14.536 & \\
\hline
\end{tabular}




\begin{tabular}{c|c|c|c|c|c|c}
\hline & Total & 11702.667 & 11 & & \\
\hline \multirow{3}{*}{ IgG } & Among groups & 26921.167 & 2 & 13460.583 & .580 & .580 \\
& Inside groups & 208935.500 & 9 & 23215.056 & \\
& Total & 235856.667 & 11 & & \\
\hline
\end{tabular}

( $\mathrm{F}$ ) value at $(0.05)=3.68$

It's shown from table ( 12 ) that variance analysis (ANOVA) among measurements outcomes ( before - after - recovery ) for passive recovery group (IgM) whereas There aren't statistically differences in the other variables. There are moral differences among the three dimensions (before - after recovery ), (F) values were (14.536), (9.310) and this value is greater than $(\mathrm{F})$ value in the table. To limit the differences indications among the three dimensions in these variables; the least moral difference test is used LSD in table (13) .

Table ( 13 )

Differences indication among measurements outcomes (before - after - recovery

), for passive recovery group in the study variables by using the least moral difference test ( LSD )

\begin{tabular}{c|c|c|c|c|c}
\hline Measurements & Groups & Averages & Before & After & Recovery \\
\hline \multirow{3}{*}{ IgM } & Before & 143.50 & & 63.75 & 45.75 \\
\cline { 2 - 6 } & After & 207.25 & 63.75 & & 18.00 \\
\cline { 2 - 6 } & recovery & 189.25 & 45.75 & 18.00 & \\
\hline
\end{tabular}

It's shown from table (13) that there are statistically differences among research's dimensions outcomes (before - after - recovery ), for passive recovery group in $(\operatorname{IgM})$ only. The differences, between before and after were for the sake of after differences and between, after and recovery dimensions for the sake of after dimension too .

Table (14)

Change ratios between before and after dimension outcomes for passive recovery group in the study variables $N=4$

\begin{tabular}{c|c|c|c|c|c|c}
\hline \multirow{2}{*}{ Variables } & \multirow{2}{*}{ Measurement unit } & \multicolumn{2}{|c|}{ Before dimension } & \multicolumn{2}{c|}{ after dimension } & \multirow{2}{*}{$\begin{array}{c}\text { Change } \\
\text { Ratio \% }\end{array}$} \\
\cline { 3 - 6 } & & $\mathbf{M}$ & $\mathbf{A}$ & $\mathbf{M}$ & $\mathbf{A}$ & 21.00 \\
\hline $\mathrm{IgA}$ & $\mathrm{Mg} / \mathrm{dl}$ & 258.5 & 11.05 & 314.50 & $21.66 \%$ \\
\hline $\mathrm{IgM}$ & $\mathrm{Mg} / \mathrm{dl}$ & 143.5 & 15.41 & 207.25 & 18.892 & $44.43 \%$ \\
\hline $\mathrm{IgA}$ & $\mathrm{Mg} / \mathrm{dl}$ & 1124.5 & 16.15 & 1241.25 & 211.263 & $10.38 \%$ \\
\hline
\end{tabular}

It's shown from table (14) that the change ratios in the variables (IgA), (IgM), (IgG) between after and recovery dimension for passive recovery group were $(10.38 \%-44.43 \%)$.

Table ( 15 )

Change ratios between after and recovery dimensions outcomes for passive recovery group in the study variables

$$
\mathbf{N}=4
$$

\begin{tabular}{c|c|c|c|c|c|c}
\hline \multirow{2}{*}{ Variables } & \multirow{2}{*}{$\begin{array}{c}\text { Measurement } \\
\text { unit }\end{array}$} & \multicolumn{2}{|c|}{ After dimension } & \multicolumn{2}{c|}{ Recovery . dimension } & \multirow{2}{*}{$\begin{array}{c}\text { Change } \\
\text { Ratio \% }\end{array}$} \\
\cline { 3 - 6 } & $\mathbf{M}$ & $\mathbf{A}$ & $\mathbf{M}$ & $\mathbf{A}$ & 57.102 & $10.33 \%$ \\
\hline $\mathrm{IgA}$ & $\mathrm{Mg} / \mathrm{dl}$ & 314.50 & 21.00 & 282.00 & $53 \%$ \\
\hline $\mathrm{IgM}$ & $\mathrm{Mg} / \mathrm{dl}$ & 207.25 & 18.892 & 189.25 & 21.807 & $8.68 \%$ \\
\hline $\mathrm{IgA}$ & $\mathrm{Mg} / \mathrm{dl}$ & 1241.25 & 211.263 & 1193.00 & 156.64 & $3.887 \%$ \\
\hline
\end{tabular}


It's shown from table ( 15 ) that the change ratios in the variables $(\operatorname{IgA})$, (IgM), (IgG) between after and recovery dimensions for passive recovery group were $(3.88 \%-10.33 \%)$.

Table ( 16 )

Variance analysis among the after dimensions outcomes for the three experimental group (cold water immersion - massage - passive recovery) in the study variables

\begin{tabular}{|c|c|c|c|c|c|c|}
\hline Measurements & $\begin{array}{l}\text { Source of } \\
\text { variance }\end{array}$ & Total squares & $\begin{array}{l}\text { Degree of } \\
\text { liberty }\end{array}$ & $\begin{array}{c}\text { Average of } \\
\text { squares total }\end{array}$ & F. value & Indication \\
\hline $\operatorname{Ig} \mathrm{A}$ & $\begin{array}{l}\text { Among groups } \\
\text { Inside groups } \\
\text { Total }\end{array}$ & $\begin{array}{c}15.167 \\
2452.500 \\
2467.667\end{array}$ & $\begin{array}{c}2 \\
9 \\
11\end{array}$ & $\begin{array}{c}7.583 \\
272.500\end{array}$ & .028 & .973 \\
\hline $\operatorname{Ig} M$ & $\begin{array}{l}\text { Among groups } \\
\text { Inside groups } \\
\text { Total }\end{array}$ & $\begin{array}{c}10.500 \\
2715.500 \\
2726.00\end{array}$ & $\begin{array}{c}2 \\
9 \\
11\end{array}$ & $\begin{array}{c}5.250 \\
301.722\end{array}$ & .017 & .983 \\
\hline IgG & $\begin{array}{l}\text { Among groups } \\
\text { Inside groups } \\
\text { Total } \\
\text { Inside groups } \\
\text { Total }\end{array}$ & $\begin{array}{c}1857.167 \\
396930.500 \\
398737.667 \\
25423.500 \\
25502.667\end{array}$ & $\begin{array}{c}2 \\
9 \\
11 \\
9 \\
11\end{array}$ & $\begin{array}{c}903.583 \\
44103.389 \\
2824.833\end{array}$ & .020 & .980 \\
\hline
\end{tabular}

( $F$ ) value at $(0.05)=3.68$

In table ( 16 ) there aren't any statistically differences among the after dimensions results in the variables $(\operatorname{Ig} A)(\operatorname{IgM})(\operatorname{IgG})$ for the three experimental groups .

\section{Table ( 17 )}

Variance analysis among the second after dimensions outcomes for the three experimental group (cold water immersion - massage - passive recovery) in the variables

\begin{tabular}{|c|c|c|c|c|c|c|}
\hline Measurements & $\begin{array}{l}\text { Source of } \\
\text { variance }\end{array}$ & Total squares & $\begin{array}{c}\text { Degree of } \\
\text { liberty }\end{array}$ & $\begin{array}{c}\text { Average of } \\
\text { squares total }\end{array}$ & F. value & Indication \\
\hline $\operatorname{Ig} \mathrm{A}$ & $\begin{array}{l}\text { Among groups } \\
\text { Inside groups } \\
\text { Total }\end{array}$ & $\begin{array}{l}14018.000 \\
20877.000 \\
34895.000\end{array}$ & $\begin{array}{c}2 \\
9 \\
11\end{array}$ & $\begin{array}{l}7009.000 \\
2319.667\end{array}$ & 3.922 & .099 \\
\hline $\operatorname{IgM}$ & $\begin{array}{l}\text { Among groups } \\
\text { Inside groups } \\
\text { Total }\end{array}$ & $\begin{array}{c}7827.167 \\
8163.750 \\
15990.917\end{array}$ & $\begin{array}{c}2 \\
9 \\
11\end{array}$ & $\begin{array}{c}3913.583 \\
907.083\end{array}$ & 4.314 & .049 \\
\hline $\mathrm{IgG}$ & $\begin{array}{l}\text { Among groups } \\
\text { Inside groups } \\
\text { Total }\end{array}$ & $\begin{array}{c}78266.000 \\
90035.000 \\
168301.000\end{array}$ & $\begin{array}{c}2 \\
9 \\
11\end{array}$ & $\begin{array}{c}39133.00 \\
10003.889\end{array}$ & 4.912 & .060 \\
\hline
\end{tabular}

( $\mathrm{F})$ value at $(0.05)=3.68$

It's shown from table ( 17 ) that variance analysis (ANOVA) among the second after dimensions outcomes for the three experimental groups (cold water immersion - massage - passive recovery) there are moral differences among all after dimensions whereas $(\mathrm{F})$ value is between (3.922-8.783) and this value is greater than $(\mathrm{F})$ value in the table at (.05). To limit the moral differences among the three dimensions; the least moral difference test is used LSD in table (18) . 


\section{Table ( 18 )}

Differences indication among the second after dimensions for the three experimental groups (cold water immersion - massage - passive recovery) in the study variables by using the least moral difference test LSD .

\begin{tabular}{c|c|c|c|c|c}
\hline Measurements & Groups & averages & $\begin{array}{c}\text { Cold water } \\
\text { immersion }\end{array}$ & massage & $\begin{array}{c}\text { Passive } \\
\text { recovery }\end{array}$ \\
\hline \multirow{2}{*}{$\operatorname{IgA}$} & Cold water immersion & 203 & & 63.50 & 79.00 \\
& $\begin{array}{c}\text { Massage } \\
\text { Passive recovery }\end{array}$ & 266.50 & 63.50 & & 15.50 \\
\hline \multirow{2}{*}{$\mathrm{IgM}$} & Cold water immersion & 127 & 79.00 & 15.50 & 62.25 \\
& $\begin{array}{c}\text { Massage } \\
\text { Passive recovery }\end{array}$ & 163.50 & 36.50 & 36.50 & \\
& Cold water immersion & 995 & 62.25 & 25.75 & 25.75 \\
\hline \multirow{2}{*}{$\mathrm{IgG}$} & Massage & 1104 & 104 & 109 & 198 \\
& Passive recovery & 1193 & 198 & 89 & 89 \\
\hline
\end{tabular}

It's shown from table ( 18 ) that tree are statistically differences among the three dimensions outcomes in the study variables $(\operatorname{IgA})(\operatorname{IgM})(\operatorname{IgG})$. The differences between the cold water immersion and massage were for the sake of massage and between massage and passive recovery were for the sake of passive recovery .

\section{Secondly : research's debate and explanation of outcomes}

The research's debate and explanation of outcomes will be done according to the sequence of research's inquiries .

\section{First Question :}

What are the changes of concentration ratios occurred in $(\operatorname{IgA})(\operatorname{IgM})$ (IgG) in the blood in the after dimension as a result of weekly intensive load training cycle for young swimmers?

It's shown from tables $(6,10,14,16)$ that there's an increase in the levels concentration in the immunoglobulin ( $\operatorname{Ig} A, \operatorname{IgM}, \operatorname{IgG})$ in the blood in the after dimension as are result of intensive training loads for swimmers the same outcomes of zkovska and others (2017) aiming to identify the super marathon race $(100 \mathrm{~K} . \mathrm{M})$ in the cold conditions (temp from $-1^{\circ}$ to $\left.+1^{\circ}\right)$. The most important outcomes were the increase of white blood balls; neutrophils and monocytes and concentration level of (IgG) . Rania Muhammad Abdullah gharieb's study (2010) The study aimed to identify the impact of resistance training by elastic ropes on the concentration of steel cooling and immune proteins (IGG,IGM,IGA) in the blood. In addition to the level of digital achievement in individual games ( playing by one - racket with right hand playing by one racket with left hand - playing with two front rackets - playing with two back rackets ) for young speed ball players under (18) yrs the study sample contained (10) young speed ball players under (18) yrs. The outcomes given that the proposed resistance trainings by elastic ropes lead to increase the concentration of stcelcooline and immune proteins (IGG,IGM,IGA) in the blood for speedball female players. Also, there's an increase in the after dimension more than the before dimension in the level of concentration for 
(IGG,IGM,IGA) in the blood the ratios of betterment were $(4.99 \%: 13.83 \%)$. Andrew's study and others (2009) mentioned that running for (60mins) on moving wire at $(75 \%)$ speed of oxygen concentration maximum made an increase in the levels of concentration for ( $\operatorname{Ig} A, \operatorname{IgM}, \operatorname{IgG})$. Ihab Sabry Muhammad Youssef's study (2005) aimed to identify the effectiveness of intensive load on the ratio of the concentration of immune proteins (IgM) in the blood for wrestlers. The most important outcome was an increase in the immune proteins in as a result of regular physical training. That idea Ahmad NasrelDin (2013) assured that sport and physical load - comparing with recovery represent stress on the different parts of body leading to an increase the white blood cells so the immune system is efficient. Arman jalili (2015) Ferrari (2013), Gelson and others (2007) Halson sl (2003) Rosa and others (2014) and Nieman D.C and others (1994) indicated that the body immune function efficiency is affected positively or passively according to the type; period and tension the training used because the regular fair trainings lead to increase the immune functions whereas the long intensive trainings lead to decrease the immune function and may cause diseases. Emily and other (2011) assured that the multi-stress may lead to suppression of immunoglobulin and lead to decrease in the immune system and may cause infection. On the contrary the researcher noticed that there are many other studies' outcomes which tried the after dimension after long periods of training (immune system adaptation for athletes in different sports led to decrease levels of concentration the immunoglobulin. Lee and others (2015) after a training program for (12) weeks for judo players. Ferrari's sand others study (2013) during (29) weeks during the competition period for cyclists. Cordova's study (2010) after a training program for (4) months for volley ball players. Petibois's study (2003) after a training program for (12) months for rowing players. All those studies referred that the decrease of the levels of concentration the immunoglobulin after long different periods more that the periods of preparation for athletes by performing and repeating the training loads for long periods lead to adaptation for immune system response. They also referred that the increase of effort and tiredness may cause diseases like upper respiratory tract inflammation (URTI)all season. So the researcher inferred that sporting training is considered one of the influences which urge the immune system and may change the responses for swimmers. The responses rely on training program done the period continued and the training tension implemented specially before competitions because they are connected with pressures of training loads or psychological sides which led to increase the immune system responses for swimmers and also to increase the concentration levels of immunoglobulin (IGA-IGM-IGG) and increasing the antigens to protect swimmers infection and diseases.

The inability of the immune system to perform its defense tasks may expose the player to infection as a result of weak- resistance for swimmers 
leading to shortage in the implementation of the training program and wasting a lot of effort time and money for years for athletes.

Gjohn and others (2018) assured that the goals of sporting training to keep the athletes' health and to protect them from diseases. Though they are exposed to diseases more than non- athletes during the sporting training periods specially intensive training in spite of the athletes with high levels have no shortage of immune; that because of decreasing the infections for athletes. Illegal intensive training programs lead to overtraining and intensive training could lead to immune system depression or decreasing infection resistance as a result of a shortage in the natural immune functions. Morgaw's study (2016) assured that the influence of training units to immune response is urgent to get enough period of training and adaptation for the training loads; besides prohibiting the passive impact on health and the weak sporting performance .

Second Question: what are the changes occurred in the concentration ratios (IGA), (IGM), (IGG) in the blood in the recovery dimension by using recovery means. (cold water immersion - massage - passive recovery) for young swimmers ?

It's shown from tables $(7,11,15)$ that the recovery means using (cold water immersion - massage - passive recovery) led to decrease the concentration levels of immunoglobulin (IGA), (IGM), (IGG) in the blood in the recovery dimension with different change ratios in the three groups for swimmers, (the change ratio \%) for cold water immersion group in the study's variables (IgA), (IgM), (IgG) was $(21.40 \%-38.04 \%)$ and the massage group was $(10.73 \%$ $20.35 \%)$ and the passive recovery was $(3.88 \%-10.33 \%)$. That indicates the recovery means used to depress the increase in the study's variables in the after dimension in the recovery dimension. The researcher indicated that using the cold water immersion and massage influence on the different body's systems like the nervous system which controls the body's systems, consequently the immune system . those influences activate the blood circulation and reach the pure blood to the nervous system which affects on the skin's cells; muscles; tendons and joints in a shape of nervous excitations to stimulate the brain and the nervous centers responsible for activities and different functional responses to activate the secretion of (Beta Endorphin) contributing to decrease the muscular pain; to activate the structure operations and getting rid of tiredness, furthermore to decrease the muscular pain and physical strain by decreaseing the concentration ratio of muscular (troponin) and (creatine kens) which are responsible for pain and muscular impair resulting from intensive physical performance. The increase of oxygen and Miloglobullin of muscles sharing in the physical performance and contributing to decrease the pressures occurred on the athlete to stimulate the parasympathetic system to depress the responses of immune globulin in the immune system in the recovery dimension indicating the ability of recovery means to decrease all the influences which led to stimulate the variables connected with the immune system after finishing the 
weekly load cycle indicating the ability of recovery means to decrease the immune weakness and diseases for swimmers (1:47), (11:97), (15:24,25), (16:4), (24), (26), (42). The researcher noticed that the rare studies about the impact of different recovery mean on the immunoglobulin in the blood in the sporting field so, this study is just a try to identify the direct relationships among recovery means; training loads and immune system to prepare the athletes particularly with intensive high levels.

Abul-Ela Ahmad Abdul-Fattah(1998)(2) assured that acknowledge the result of training units on the responses of the immune system is too urgent to protect athletes from the passive influences . he indicated that the effective factors to decrease the immune are the training loads, so good planning is needed for training loads and caring the individual differences and the other environmental factors affect are studied (environmental changes - atmosphere - water temperature - gender - age - physical fitness - available training abilities ) on the immune system of athletes and caring the means of different recovery .

In addition to it's shown from tables (17), (18) that cold water immersion has more effective than massage and passive recovery as a means of recovery to decrease the concentration levels of immunoglobulin ( $\operatorname{IgA}-\operatorname{IgM}-$ $\operatorname{IgG}$ ) in the blood for swimmers after performing intensive training. Sam Pooley's and others study (2019)(56) aimed to compare between cold water immersion ( CWI ) and active recovery ( AR ) and static stretching to recovery the muscles after finishing some competitive soccer matches for juniors. That study contained (15) players between (16-20) yrs. The persons of sample played (9) matches of soccer; it contained Creatine Kenz (CK), counter movement jump act (CMJA), and muscle soreness evaluating these variables with the before dimension and after the performance directly and after (48) hrs. of competitive matches. It attained to that cold water immersion and active recovery are considered means of recovery more than static stretching (SS) . Sanchez -Urena's study (2018) aimed to compare between (2) protocols of cold water immersion on the recovery after matches for handball female players. That study contained (31) handball players divided into two groups. The $1^{\text {st }}$ group of continuous cold water immersion $(\mathrm{N}=12)$ for $(12$ minutes temp). ( $\left.14 \mathrm{C}^{\mathrm{o}} \pm 0.5^{\circ}\right)$, whereas the $2^{\text {nd }}$ group makes the intermittent cold water immersion $(\mathrm{N}=11)\left(4 \times 2 \mathrm{~m}\right.$. temp. $14 \mathrm{C}^{\mathrm{o}} \pm 0.5+1 \mathrm{~m}$. out of water), controlling group $(\mathrm{CG})$ makes the passive recovery $(\mathrm{N}=9)$. the outcomes of study indicated that the impact of the two programs used to decrease the muscular pain directly after the training compared with the controlling group. Delextrat's study and others (2012) aimed to compare between the impact the intermittent cold water immersion and massage to recovery after competitive matches for basketball players. The study indicated that the tiredness is less for the female players after cold water immersion than the massage. The study generally recommended that the cold water immersion is better than the massage in the recovery after basketball matches. 


\section{Ihab Muhammad Ismael \& Osama Fouad Muhammad Abdul-} Moniem (2016) study under the headline of the impact of the ice pads on concentration ratio (TBARS) and (GSH.PER) enzyme during the air glucose as signs of oxidative pressure for marathon players the outcomes of study indicated the using the ice pads as means of recovery limited the oxidative pressure after the airy training performance . Arroyo's study and others (2009) aimed to identify the influence of massage on immune functions and hormones for active athletes after intensive training after the repetition of (Wingate) tests. The study contained (60) active athletes made warming up followed by evaluating the anaerobic ability by test (30) secs . for the samples . after that the random recovery massage is done for the muscles (40mins) the other illusive group (electric treatment for 40mins) the outcomes of study made a statistic degree (IgA) the study recommended that it's better to use the massage as a means of recovery for the transient immunosuppression case resulting from the exercises for the female athletes.

The researcher referred that the training load is considered the effective factors on the immune system to protect the body's athletes from diseases and attaining to overtraining may lead to decrease the immune system functions and also to decrease the ability of body infection because the change of leukocyte counts and immunoglobulins. So the using of recovery means make the right balance to keep away from the overtraining which may cause tiredness and imbalance in the immune system. The researcher noticed the rare scientific studies in this field handling the different recovery means and its affection immunoglobulins in the blood in the sporting field.

\section{Conclusions}

1- Weekly intensive load cycle during the period before the competitions contributed to increase the level of concentration of the immunoglobulin (IgA - IgM - IgG) in the after dimension.

2- Decreasing the levels of concentration the immunoglobulin ( $\operatorname{Ig} \mathrm{A}-\operatorname{IgM}$ $\mathrm{IgG}$ ) in the blood by the different means of recovery (cold water immersion - massage - passive - recovery).

3- Cold water immersion led to decrease the levels of concentration of the immunoglobulin (IgA - IgM - IgG) in the blood with change ratios between $(21.40 \%-38.04 \%)$ for young swimmers.

4- Massage led to decrease the levels of concentration the immunoglobulin (IgA - IgM - IgG) in the blood with change ratios between $(10.73 \%$ $20.35 \%$ ). For young swimmers.

5- Passive recovery led to decrease the levels of concentration the immunoglobulin ( $\operatorname{IgA}$ - IgM - IgG) in the blood with change between $(3.88 \%-10.33 \%)$ for young swimmers.

6- Cold water immersion is considered better than massage and passive recovery as a recovery means to decrease the levels of concentration the 
immunoglobulin (IgA - IgM - IgG) in the blood after intensive training done for young swimmers.

\section{Recommendations}

1- Taking care of biochemical variables measurements as an indicator for immune system efficiency in the body during the training season to give the case of biological athletes.

2- Using the cold water immersion as a means of recovery to help the immune system to protect the body through training and intensive competitions which the tension and pressure are more.

3- Using the sophisticated sets to implement the different recovery programs during the training season to get definite and accurate outcomes.

4- All the members of sport and athletes should be committed with the guiding principles to keep the immune strong for athletes and to put an end for the training pressure. These principles are connected with feeding training and recovery .

5- More applied studies should be done to clarify the relationship between the immune system responses and the different training load cycles (response - accommodation) and the means of recovery clearly.

6- More applied studies should be done for physical, physiological and biochemical changes connected with the immune system for the physical activities specially the juniors.

7- More applied studies should be done to identify the effect of dietary supplements and sleep for athletes and the relation with the immune system to increase its efficiency during the training and different contests.

8- More applied studies should be done to identify the effect of the changes that occurred as a result of sporting training in the immune functions to make infection and diseases for athletes.

\section{References}

1- Abul-Ela Ahmed Abdul-Fattah (1999): Recovery in the sport field, $1^{\text {st }}$ edition, Dar Al-Fekr Al-Arabi, Cairo.

2- Abul-Ela Ahmed Abdul-Fattah (1998): Sport biology \& athlete's health, $4^{\text {th }}$ edition, Dar /El-Fekr Al-Arabi, Cairo.

3- Abul-Ela Ahmed Abdul-Fattah (1997): Sport training \& physiological bases, $1^{\text {st }}$ edition, Dar El-Fekr El-Arabi. Cairo.

4- Abul-Ela Ahmed Abdul-Fattah, Laila Salah El-Din Saleem (1999): Sport and Immune system, $1^{\text {st }}$ edition, Dar El-Fekr El-Arabi, Cairo.

5- Abul-Ela Ahmed Abdul-Fattah, Muhammed Sobhi Hassanien (2009): Alternative medicine encyclopedia, Al-Ketab center advertising, Cairo.

6- Ahmed Nasrel-Din Sayed (2013): Principles of sport physiology, $1^{\text {st }}$ edition, Cairo.

7- Ekhlas Muhammad Abdul-Hafeez, Moustafa Hussien Bahi, Ade; Muhammad Al Nashar (2004): Statistic analysis in educational sciences (theories, applications, exercises) Al Anglo Egyptian bookshop, $1^{\text {st }}$ edition, Cairo. 
8- Ihab Sabry Muhammad Youssef (2005): Highly-tension physical load effect on concentration ratio of immune proteins in blood vaccine for wrestlers; a research ; high institute of general health, Alex university.

9- Ihab Muhammad Mahmoud Ismael, Osama Fouad Muhammad Abdul-Moniem (2016): Effectiveness of ice pads on (ottdG8) and some oxide variables during air glucose as signs for oxide pressure for marathon racers, European magazine for sport science technology, $8^{\text {th }}$ no.

10- Bahaa El-Din Ibrahim Salama (2008): Living chemical characteristics for sport physiology, Dar Al-Fekr Al-Arabi, $1^{\text {st }}$ edition, Cairo.

11- Hussein Ahmed Heshmat, Moustafa Hussien Bahi, Nabil AL-Sayed Hassan (2002): Reference in physiological psychology (theories, analysis, applications), $1^{\text {st }}$ edition Al-Anglo Egyptian Bookshop, Cairo.

12- Hussien Ahmed Heshmat, Nader Muhammad Shalaby, Abdul-Mohsen Mubarak Al-Azmy (2013): Sport physiology encyclopedia, $1^{\text {st }}$ edition, Dar Al-Fekr AlArabi, Cairo.

13- Rania Muhammed Abdullah Gharieb (2010): The effect of resistance training on concentration of steelco line ; immune proteins and digital achievement in individual playing for speed ball female players, a research, $5^{\text {th }}$ ni. Zagazig university.

14- Resan Kharbeet, Abu-Ela Ahmed Abdul-Fattah (2016): Sport training, Al-Ketab for advertising centre, $1^{\text {st }}$ edition.

15- Muhammad Kadry Bakry (2001): Traditional and oriental massage in the alternative medicine, Dar Al-Manar for printing, $1^{\text {st }}$ edition, Cairo.

16- Muhammad Mahmoud Abdul-Zaher (2002): The effect of some recovery means on the speed of hectat enzyme d'Hydrogens and chiriatine Kenz for athletes (comparing study), unpublished $\mathrm{PhD}$, faculty of physical education for men in cairo, Healwan university.

17- Alexander J, Koch.(2010).Immune response to resistance exercise.Am J Lifestyle Med, 11,244-52.

18- Andrew M, Smith L, \& Wadee A.(2009). immunoglobulin and creatine kinase response in black and white males after muscle-damaging exercise.SAJSM, 21:47-52.

19- Arman Jalili, Hossein Ali Khazae, \&Zari Sanchuli.(2015).The Effect of an Intense Anaerobic Exercise Session on Serum Levels of IgG, IgM and IgA in Handball, Volleyball and Climbing Sports. International Journal of Medical Laboratory, 2(1):50-57.

20- Arroyo-Morales M,Olea N, Ruiz C,Matinez M.(2009). Massage after exerciseresponses of immunologic and endocrine markers: a randomized single-blind placebo-controlled study. J Strenght CondRes,23(2):638-44.

21- Arwel Wyn, Glen Davion.(2019). Exercise, Immunity, and Illness.Muscle and Exercise Physiology. Chapter 15, Pages 317-344.

22- Brown, F., Gissane, C., Howatson, G., van Someren, K., Pedlar, C., \& Hill, J. (2017).Compression Garments and Recovery from Exercise.A Meta-Analysis.Sports Med , 22, 1-23.

23- Calleja-González, J., Terrados, N., Mielgo-Ayuso, J., Delextrat, A., Jukic. I., \&Vaquera, A.(2016). Evidence based post-exercise recovery strategies in basketball. Phys Sportsmed, 44(1),74-78.

24- Christa Magrieta Koekemoer. (2010). The effects of water immersion on the recovery and performance of competitive cyclists.the degree of Master in Sport Science at the University of Stellenbosch. 
25- Córdova A, Sureda A, Tur J.A, Pons A.(2010).Immune response to exercise in elite athletes during the competitive season.J. Physiol. Biochem,66:1-6.

26- D. M. Bailey, S. J. Erith, P. J. Griffin, A. Dowson, D. S. Brewer , N. Gant, and C. Williams.(2007).Influence of cold-water immersion on indices of muscle damage following prolonged intermittent shuttle running, Journal of Sports Sciences, Vol 25(11), P : $1163-1170$.

27-David C , Nieman , Laurel M , Wentz (2019).The compelling link between physical activity and the body's defense system. Journal of Sport and Health Science, 8(3), 201-217.

28- David C\& Nieman Brandt D.(2019). Exercise immunology: Future directions. Journal of Sport and Health Science, 37: 412-415.

29- David C. Nieman \&Bente K. Pedersen.(2012).Exercise and Immune Function.Sports Medicine , 27, 73-80.

30- Delextrat, A., Calleja-González, J., Hippocrate, A., \& Clarke, N.D.(2012). Effects of sports massage and intermittent cold-water immersion on recovery from matches by basketball players.Journal of Sports Sciences, 31(1), 11-19.

31-Djken H, Kelle M, \&Colpan L.(2000).Effect of physical exercise on complement and immunoglobulin levels in wrestlers and sedentary controls. J Med School, 27:39-45.

32-Emily C P LaVoy, Brian, K., \& Richared, J.(2011).Immune responses to exercising in a cold environment.Wilderness Environ Med, Dec;22(4):343-51.

33- Ferrari,C.A.Gobatto,F.B.Manchado-Gobatto,.(2013).trainingload,immune system,upper respiratory symptoms and performance in well-trained cyclists throughouta a competitive season.Biol Sport,30(4): 289-94.

34- Gjohn Mullen (2018). Effects of Intensive Training on the Innate Immune System in Swimmers. Swimming Science Resources,

35-Gleeson M.(2007).Immune function in sport and exercise. J.Appl. Physiol,103:693-699.

36- Graham, A. (2017). The effects of CWI and CWT on performance recovery following high-intensity exercise: A systematic review and meta-analysis. J. Aust. Strength Cond. 2,(2) 59-65.

37- Guo J, Li L,Gong Y,\&Zhu R (2017). Massage Alleviates Delayed Onset Muscle Soreness after Strenuous Exercise:A Systematic Review and Meta-Analysis.Front Physiol,27(8),747.

38- Halson S.L, Lancaster G, Jeukendrup A.E, \& Gleeson M.(2003). Immunological responses to overreaching in cyclists. Med. Sci. Sports Exerc. 35:854-861.

39- Hanns C.G, Andreas M, Wolfgang S,Markus M, Karl K, Eberhard K, \&Lothar R.(2002).IgG, IgA, IgM, and Plasma Volume Changes During Long-distance Running.13:15-20.

40- Imanipour V, Shahedi V, \&Armandnia M.(2009).The effects of physical activity on homoral immune system (IgA, IgG, IgM). Procedia Soc Behav Sci.1:2718-21.

41- Issurin V.B.(2010). New horizons for the methodology and physiology of training periodization.Sports Med.40:189-206.

42- Karacabey K, Saygin O, Ozmerdivenli R, Zorba E, Godekmerdan A, Bulut V.(2005). The effects of exercise on the immune system and stress hormones in sportswomen.Neuro. Endocrino,26:361-366.

43- Keyvan Hejazi, Seyyed-Reza.(2012).Influence of Selected Exercise on Serum Immunoglobulin, Testosterone and Cortisol in Semi-Endurance Elite Runners. Asian J Sports Med.3(3): 185-192. 
44- Kuchin RV, Nenenko ND, Chernitsyna NV \&Fiziologiia Cheloveka.(2017).Some Immunophysiological Features of Sport Activity in the Climatic and eographical Conditions of the Middle Ob Region. 43(1):121-125.

45-Lee N,Kim J,Hyung GA,Park JH,Kim SJ,KimHB, \&Jung HS(2015).Training Effects on Immune Function in Judoists. Asian J Sports Med,Sep 6(3).

46- Leeder, J., Gissane, C., Van Someren, K., Gregson, W., \& Howatson, G. (2012). Cold water immersion and recovery from strenuous exercise:A meta-analysis. British J Sports Medicine, 46, 233-240.

47- Malihe Saeedy, Nahid Bijeh \&Mahtab Moazzami (2018). The Effect of Six Weeks of High-Intensity Interval Training With Zinc Supplementation on Some Humoral Immunity Markers in Female Futsal Players. Annals of Applied Sport Science 6(1):11-19.

48- Moreira A, Delgado L, Moreira P, \&Haahtela T.(2009). Does exercise increase the risk of upper respiratory tract infections?.British Medical Bulletin , 90:111131.

49- Morgado JP, Monteiro CP, Teles J, Reis JF.(2016).Immune cell changes in response to a swimming training session during a 24-h recovery period. Appl Physiol Nutr Metab. May;41(5):476-83.

50- Nieman D.C, Nehlsen-Canarella S.L.(1991) The effects of acute and chronic exercise on immunoglobulins. Sports Med. 11:183-201.

51- Nieman D.C.(1994). Exercise., infection and immunity. Int. J. Sports Med, 15:131-141.

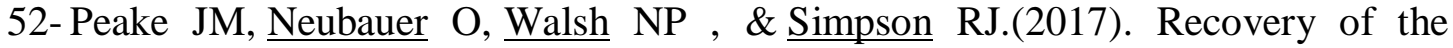
immune system after exercise. J Appl Physiol, 122(5):1077-1087.

53- Petibois C, Cazorla G, Déléris G.(2003).The biological and metabolic adaptations to 12 months training in elite rowers.Int. J. Sports Med. 24:36-42.

54- Pyune,DB.,Gleeson.(1998).Effects of intensive exercise training on immunity in athletes.Int J Sports Med, 19(2), 191-4.

55- Rosa L , Teixeira A , Lira F \& Tufik S.(2014).Moderate acute exercise (70\% VO2 peak) induces TGF- $\beta, \alpha$-amylase and $\operatorname{IgA}$ in saliva during recovery. Oral Dis, 20(2):186-90.

56-Sam Pooley, Owen Spendiff, Matt Allen \& Hannah Jayne Moir (2019).Comparative efficacy of active recovery and cold water immersion as postmatch recovery interventions in elite youth soccer. Journal of Sports Sciences , $28,1-9$.

57-Sánchez-Ureña, B., Martínez-Guardado, I., Espinoza-Acuña, G., CamachoCardeñosa, M., Camacho-Cardeñosa, A., Timón, R., \& Olcina, G. (2018). Comparison of cold water immersion protocols in female handball players after match training. Journal of Human Sport and Exercise, 13(2), 363-374.

58-Sánchez-Ureña. B., Martínez-Guardado, I., Crespo, C., \& Olcina, G (2017). The use of continuous vs. intermittent cold water immersion as a recovery method in basketball players after training: a randomized controlled trial, The Physician and Sportsmedicine, 12(2),151-4.

59- Sinnott-O'Connor C, Comyns TM, Nevill AM, \&Warrington GD.(2018). Salivary Biomarkers and Training Load During Training and Competition in Paralympic Swimmers.Int J Sports Physiol Perform, 1;13(7):839-843.

60- Tejero-Fernandez V, Membrilla-Mesa M,\& Galiano-Castillo N. (2015).Immunological effects of massage after exercise:A systematic review. Phys Ther Sport,16(2),187-92. 
61- Verde T, Thomas S, \&Moore R.(2007).Immune responses and increased training of the elite athlete. J Applied Physiol,103:14-5.

62- Wataru Aoi, Yuji Naito.(2019).Immune Function, Nutrition, and Exercise. Chapter 7, Pages 83-95.

63-Zkovska A,Knechtie B, Chlibkova D,Rosemann T , \& Nikolaids PT.(2017).The Effect of a 100-km Ultra-Marathon under Freezing Conditions on Selected Immunological and Hematological Parameters. Front Physiol. 12(8):638.

Reference of Internet :

64- www.google.com/search?q=athletics $\% 2 B+C$ irculating + immunoglobulins $+o f+\% 2$ $\mathrm{B}+$ cold+water+immersion\&oq=athletics $\% 2 \mathrm{~B}+$ Circulating+immunoglobulins + of + $\% 2 \mathrm{~B}+$ cold+water+immersion \&aqs=chrome..69i57.1416j0j8\&sourceid=chrome \&i $\underline{\mathrm{e}=\mathrm{UTF}-8}$

65- www.google.com/search?source=hp\&ei=XKxMXdaCKMi2aZku5AH\&q=serum+levels+of+immunoglobulins\&oq=serum+levels+of+immunoglobulins

66- www.sciencedirect.com/topics/immunology-and-microbiology/immunoglobulin-bloodlevel. 